\title{
Research on the Cultivation of Business English Interpreting Ability Based on Schema Theory
}

\author{
Shaolin Wang \\ Jilin Business and Technology College, Jilin Province, Changchun, 130507
}

Keywords: Cultivation, Business English, Interpreting Ability, Schema Theory

\begin{abstract}
With the exchange and development of world culture, English has been paid more and more attention. In order to meet the needs of the market, people gradually developed business English, that is, for the needs of professional English. In the process of cultivating business English interpreting ability, it is necessary to strengthen the understanding of business English and the cultivation of students' ability to enable students to establish business English interpreting ability . Schema theory is the main way of learning in the cultivation of English interpreting ability. This paper expounds the theory of schema and business English, and introduces the application of schema theory in the cultivation of business English interpreting ability. Finally, some suggestions are put forward to promote the improvement of business English interpreting ability.
\end{abstract}

\section{Introduction}

With the gradual establishment of a market economy, the importance of business English in the world economy is self-evident. For the cultivation of business English is not a single theoretical knowledge as the premise, it also needs more language conversion ability training,which in other words refers to the cultivation of English interpreting ability. Business English in the application process needs three aspects of training which are the corresponding understanding, the ability to express,and the ability to train. The application of graphic theory can improve the efficiency of business English interpreting ability and further strengthen the development of business English interpreting ability.

\section{The Schema Theory}

Graphic theory mainly refers to a certain subject to the organization for knowledge and information, and ultimately show a certain level of basic theoretical way. The origin of the graphic theory can be traced back to the Kantian period. Kant put forward the schema theory in his philosophical writings. With the gradual study of the theory of modernity, the author of the modern psychology suggests that the structure mainly refers to the structure or organization of the action. To the famous Swiss psychologist, educator Piaget, as the representative, pointed out that "the icon is displayed as long as a fixed action of the structure or organization ." With the development of history, the study of graphic theory has been deepened. In the late 1970s, the theory of graph theory has gradually formed a theoretical science. It is mainly a kind of knowledge that has certain ability and expression.Illustration is a way in which knowledge is made up of parts, where a component is called a variable or consists of different variables, each of which can be called an icon. The development of cognitive psychology for the theoretical picture began mainly in the mid-1970s, through the icon theory to help people understand the social phenomenon, so that people establish a good sense of social awareness. The development of graphic theory promotes the development of human understanding of social cognition and knowledge structure. By the end of the 1990s, schema theory was widely used in cross-cultural fields.

Schema theory is a new reading theory in recent years. The so-called schema refers to the characterization and storage of knowledge organized around a particular subject. The theory emphasizes that people already have the knowledge and knowledge structure of its cognitive activities play a decisive role. According to the theory of schema, the knowledge stored in the human brain is composed of one unit. People's life to learn and master a lot of knowledge, which is 
not disorderly stored in the human brain, but around a theme linked to form a certain knowledge unit, which is called schema. Schema is a cognitive model of knowledge,which refers to a set of related events, knowledge or beliefs that constitute a stable psychological structure or network. The formation of this psychological structure mainly depends on acquired event, object, concept or concept in time and space. Knowledge often affects the problem solving in the form of schema representation. The theory of schema studies is how the knowledge is characterized, and how the representation of knowledge is conducive to the application of knowledge in its unique way. It is the result of the joint efforts of cognitive psychologists, linguists and artificial intelligence experts. However, this does not mean that the formation of the schema which is to be a variety of relevant knowledge can be integrated together. The pattern "does not reproduce the knowledge structure intact", but "reassembles the knowledge according to the specific situation" is "from a variety of sources of knowledge, which will adapt to the current situation in a certain understanding or problem solving needs of the information together "Although the schema is a kind of stereotyped or fixed knowledge of the characterization, but the formation of the schema is inseparable from the problem of growth in the context of the continuous adaptation and adjustment, this" denaturation "is often ignored for us.

American cognitive psychologist Aosu Boer stressed that meaningful learning is to link new knowledge and the original knowledge, and the new knowledge into the original knowledge structure. In view of this, the cognitive structure of students is the growth point of new knowledge, to help students establish a good cognitive structure.Schema theory has a positive effect on cognitive structure.

Schema theory is generally divided into three types: linguistic schemata and rhetorical schemata. Language schema refers to the reader's previous knowledge of language that is about speech, vocabulary and grammar, and so on. It is the basis of understanding the text of the article. Content schema refers to the meaning of language and cultural background, which are the reader's familiarity about the subject. The type of reader is the degree of understanding of the article type . In these three schemas, the language schema is to understand the basis of the text of the article, the content schema is to understand the content of the article basis, and rhetoric is the ability to call content, which are indispensable.

\section{The Business English}

Business English mainly refers to the language requirements to meet the needs of the workplace, which not only includes the cultivation of English ability, but also the need for students to Western management philosophy, work theory, work mode and other ways to cultivate the business capacity in the process of training, it needs to teach students how to communicate and communicate with foreigners. The development of business English is the main language way for the Chinese business market to join the international economy quickly. For business English and English, many people will confuse the concepts and think that there is no need to add "business" before English ability training. In fact, the two core ideas are different, mainly refers to a simple English language communication, business English is the combination of English and business, in the training of English, people also need to pay attention to business, and business theory. Therefore, in the training of students' business English ability, we should focus on the process of language formation, including essential business English interpretation skills. Business English interpretation is a process of translating English into Chinese accurately by verbal form of English information that is understood and perceived by itself, so that the language can be quickly converted. In the process of cultivating business English interpreting ability, it is necessary to cultivate in language comprehension, language form and language elaboration, so as to improve the ability of business English interpreting.

\section{The Application of Schema Theory in the Cultivation of Business English Interpreting Ability}

In the Application of Language Understanding. In the process of interpreting business English, 
the understanding mainly refers to the exchange of information between the business English and the translator's brain in the information and the information obtained, and finally form their own way of understanding, and thus translated into the required language a process of information exchange and influence. The application of schema theory can improve the information capacity of the translator's own brain. The accumulation of information in the traditional business English interpreting is carried out by the conventional way. At the present stage, the accumulation of information in language comprehension is realized by using schema theory., in order to enhance the translator's ability to understand the content through the structure.

In the Application of the Language Form. In the process of interpreting business English, the interpreter needs to establish the language according to the language information of the speaker according to the relevant knowledge of the business English theory and the proficiency of the language skills needed in the communication. In the process, the language form needs to be reconstructed, so that the listener more understanding of the translation of the content. For example, in the translation of geographical geography in business English, if the English profile of a region of China is interpreted, the interpreter can translate well in Chinese language,he statement is fluent and the expression is concise.However, if it is an English interpretation of a region of foreign countries, the degree of its language and the lack of knowledge to understand the interpreter can bring a lot of problems, so that it cannot be limited in the language form of translation. Graphic theory can help interpreters understand the different forms of language in different ethnic groups and different regions, accumulate relevant knowledge, and can quickly decode language, translate from language form and improve English interpreting ability.

In the Application of Language. The use of schema theory to develop English interpreting ability can help the translator to reduce the difficulty of expression, flexible arrangement of language order, fast translation. For example, in the process of translation of a speech need to address the speech of the environment and personnel interpretation, the translator in the language of the need to meet the local characteristics and atmosphere. The growth and adjustability of the schema theory coincides with the needs of this language, and help the learners to establish a good icon to understand the information, so that the translator can articulate the language in a reasonable and flexible way. Language proficiency, also known as language, is one of the important parts of the language ability of the translator. Therefore, the translator should pay attention to the establishment of language expressive ability in business English interpreting. Using schema theory can help students to establish good language expression ability, so that the content of translation is more concise, fluent and reasonable.

\section{Measures to Improve the Training of Business English Interpreting Ability}

Create a Good Interpretation Training Environment. Environment is an indispensable factor in growth, but also one of the main factors affecting the formation. In the process of business English interpreting ability, good environmental factors are also one of the main factors influencing the ability of business English interpreting. Therefore, in the future development should strengthen the business English interpretation ability environment atmosphere. For example, the creation of a scenario simulation interpreting environment creates a favorable environment for students, and in the scenario simulation interpreting the teacher, the teacher builds a business exchange for the students and helps the students to carry out interpreting training at the exchange meeting. In addition, teachers can create a stress environment, so that students feel the real business English interpretation of the tension in the atmosphere, which will enhance students' ability to adapt to interpretation.

Expand Learning Method. In addition to the use of schema theory to carry out the cultivation of interpreting ability, we can also use the combination of situational teaching and graphic theory to cultivate English interpreting ability, so as to improve the quality of teaching. We establish a good learning mechanism to supervise students to carry out the training of interpreting ability.

Strengthen Business English Interpretation Vocabulary. Business English interpreting language vocabulary is large, and accumulation is the basic content of interpreting. In the future 
business English interpreting ability training process need to strengthen the accumulation of interpreting vocabulary. Through the application of graphic theory in business English interpreting training to help learners accumulate more language vocabulary. In the teaching process will be the same category of words to build the structure of the structure. For example, the words of the business industry class are arranged from large to small, and are classified into chemical, financial, and architectural categories for inclusion. They are subdivided from different categories, the structure helps the scholar to establish a clear word memory map. Through the icon of a variable, it can trigger a different variable. The establishment of the pictorial structure allows students to memorize English vocabulary in a fast way. In the process of interpreting, students can use short-term memory and conventional memory in two ways to alternate memory, thereby enhancing the vocabulary of the memory level. The use of symbols and digital conversion methods help students to the accumulation of vocabulary in the English interpretation, and to enhance the quality of business English translation skills.

\section{Conclusion}

The development of business English is the main way to promote social communication and development. Through the improvement of business English ability,it can achieve the continuous development of China's economy. The use of schema theory in language understanding, language form and language theory can help develop business English interpretation skills,and improve the efficiency of business English interpretation skills. However, in the future application process, we need to further strengthen the business English interpretation ability training environment, through the expansion of learning methods and enhance business English interpreting vocabulary to improve the interpreter's business English interpreting ability and to promote business English development.

\section{References}

[1] Zhang Chunyan, Chen Xin. The role of schema theory in the selection of interpretation strategies [J]. Journal of Hebei Union University (Social Science Edition). 2012 (01)

[2] Cheng Yuezhen. The composition of business English interpreting elements from Jill's interpretation model [J]. Journal of North China Electric Power University (Social Science Edition) "2010. 04."

[3] Wu Jie. Business English characteristics and translation [J]. China Science and Technology Translation. 2008 (04)

[4] Wei Wei, Liu Mingdong. Development and application of schema theory [J]. Journal of Hunan First Normal College. 2007 (01)

[5] Zhong Weihe. Interpreting curriculum and interpreting teaching principles [J]. Chinese translation. 2007 (01)

[6] Liu Mingdong, Liu Kuanping. Schema translation [J]. Foreign Language Teaching. 2004 (04) 